\title{
Failure to thrive associated with the Imerslund-Grasbeck syndrome
}

\author{
A. N. CAMPbell $\dagger$ \\ M.B. B.S., M.R.C P.
}

\author{
J. INGLIS** \\ M.B., Ch.B., M.R.C.P.
}

\author{
A. S. PAYNTER* \\ M.B. B.S., M.R.C.P. \\ Departments of Child Health, $\uparrow$ Newcastle General Hospital, \\ *Royal Victoria Infirmary, Newcastle, **Doncaster Royal Infirmary
}

\begin{abstract}
Summary
Two siblings are described who presented with failure to thrive and in whom a diagnosis of ImerslundGrasbeck syndrome was made. Following treatment with i.m. hydroxocobalamin there was a good and rapid increase in weight and their haematology returned to normal.
\end{abstract}

\section{Introduction}

Vitamin $\mathbf{B}_{12}$ deficiency in childhood is rare. Imerslund (1960) and Grasbeck et al. (1960) described a disorder due to selective vitamin $\mathbf{B}_{12}$ malabsorption associated with proteinuria. The malabsorption is not correctable by administration of intrinsic factor.

\section{Case report}

A boy was born at full term by forceps delivery with a birth weight of $2.29 \mathrm{~kg}$. He made good neonatal progress and continued to grow along the 3rd centile for weight. At the age of 18 months he began to show symptoms of lethargy, anorexia and generalized ill health. On admission, when 2 years old, his weight was below the $3 \mathrm{rd}$ centile at $9.0 \mathrm{~kg}$.

On examination he was strikingly pale and had a loud precordial systolic murmur. There were no other physical signs. His $\mathrm{Hb}$ was $5.4 \mathrm{~g} / \mathrm{dl}$; WBC $9.5 \times 10^{9} / 1$; platelets $80 \times 10^{9} / 1$. A blood film showed a picture consistent with megaloblastic anaemia with gross anisocytosis, poikilocytosis and macrocytosis. An iliac crest bone marrow biopsy showed megaloblastic anaemia with very active erythropoiesis. Serum chemistry was normal apart from an alkaline phosphatase of $784 \mathrm{i} . \mathrm{u}$./l. The 24-hr urinary protein excretion was $300 \mathrm{mg}$ with a marked albumin band on electrophoresis. There were no intrinsic or parietal cell antibodies present in his serum. Serum vitamin $B_{12}$ was $80 \mathrm{ng} / \mathrm{l}$; serum folate $11.9 \mu \mathrm{g} / \mathrm{l}$; serum iron $62 \cdot 1 \mu \mathrm{mol} / 1$ with a total iron binding capacity of $67 \mu \mathrm{mol} / \mathrm{l}$. A xylose absorption test showed a venous blood concentration of $1.8 \mathrm{mmol} / 1$ at one $\mathrm{hr}$ and 2 sweat sodium tests were within normal limits. A breath hydrogen test using a loading dose of lactulose showed no evidence of small bowel overgrowth, and a barium meal and follow-through was normal. A whole body radioactive scan using a tracer dose of $\left({ }^{57} \mathrm{Co}\right)$ cyanocobalamin showed less than $1 \%$ absorption of the vitamin at one week (normal $27-47 \%$ of dose) and a repeat using intrinsic factor failed to increase $a b-$ sorption.

During the investigations he received $220 \mathrm{ml}$ of packed red cells increasing the $\mathrm{Hb}$ to $15.2 \mathrm{~g} / \mathrm{dl}$. After the diagnosis had been made he received $4 \times 250 \mu \mathrm{g}$ hydroxocobalamin i.m. and was discharged home on the same ( 3 monthly) dose.

Follow-up studies have shown him to have maintained a normal $\mathrm{Hb}$ and serum total vitamin $\mathbf{B}_{\mathbf{1 2}}$ concentration, and he has thrived, becoming more energetic and with a good appetite. One year after starting treatment his weight is now $13 \mathrm{~kg}$ on the 10 th centile, with a height of $90 \mathrm{~cm}$.

During his admission his sister, aged 15 months, was seen. She had no physical abnormalities although her weight was $8.6 \mathrm{~kg}$ on the 10 th centile. Her $\mathrm{Hb}$ was $7 \cdot 7 \mathrm{~g} / \mathrm{dl}$ and the blood film macrocytic. Megaloblastic anaemia was confirmed on bone marrow aspiration. She was also found to have proteinuria and her serum vitamin $\mathbf{B}_{\mathbf{1 2}}$ concentration was borderline at $120 \mathrm{ng} / \mathrm{l}$. A whole body cyanocobalamin study showed no absorption of vitamin $\mathbf{B}_{12}$ with or without intrinsic factor. She was started on hydroxocobalamin $250 \mu \mathrm{g}$ i.m. and since then has thrived. Her weight is now on the 75th centile, her height $86 \mathrm{~cm}$, and $\mathrm{Hb} 12 \cdot 1 \mathrm{~g} / \mathrm{dl}$.

The mother of these siblings has a normal $\mathrm{Hb}$ and serum vitamin $B_{12}$ concentration, but unfortunately the father was not available for investigation. 


\section{Discussion}

These 2 siblings show features of ImerslundGrasbeck syndrome with a specific malabsorption of vitamin $\mathbf{B}_{12}$ leading to a severe megaloblastic anaemia associated with proteinuria. They also showed a marked failure to thrive which has responded well to treatment with parenteral hydroxocobalamin. No small bowel biopsy was performed as it was not considered justified, but xylose absorption was normal and a breath hydrogen test excluded blind loop syndrome. The fact that there was a rapid increase in weight apparently due to the parenteral hydroxocobalamin suggests that specific malabsorption of cobalamins was responsible for the failure to thrive.

Walters and Koch (1972) reported a similar case in a 16-month-old infant who gained weight from the 3rd to the 10th centile after treatment. Studies by McKenzie et al. (1972) suggest that the abnormality of vitamin $\mathbf{B}_{12}$ absorption lies in the attachment of the vitamin to the receptors in the ileum and is not associated with a morphologically identifiable lesion. $\stackrel{\otimes}{\circ}$ The mild but persistent proteinuria is unassociated. with other evidence of renal dysfunction and has $\Rightarrow$ been found in previously reported cases.

\section{Acknowledgment}

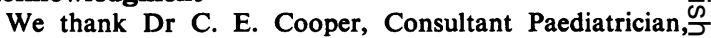
Newcastle General Hospital, for permission to report this ${ }^{\circ}$ case.

\section{References}

Grasbeck, R., Gordin, R., Kantero, I. \& Kuhlback, D.ב (1960) Selective vitamin $B_{12}$ malabsorption and proteinuria $\vec{\omega}$ in young people. Acta medica scandinavica, 167, 289.

IMERSLUND, O. (1960) Idiopathic chronic megaloblastico anaemia in children. Acta paediatrica scandinavica, 493. (Suppl 119), 1.

MACKenzie, I.L., Donaldson, R.M., TRIER, J.S. \& NAThan, V.I. (1972) Ileal mucosa in familial selective vitamin $B_{12} \sigma$ malabsorption. New England Journal of Medicine, 286, 0 1021.

WALTERS, T.R. \& KoCH, H.F. (1972) Generalized malabsorption, failure to thrive and megaloblastic anemia.o American Journal of Diseases of Children, 124, 766. 